\title{
Insulin-releasing and insulin-like activity of Agaricus campestris (mushroom)
}

\author{
A M Gray and P R Flatt \\ School of Biomedical Sciences, University of Ulster, Cromore Road, Coleraine BT52 1SA, UK \\ (Requests for offprints should be addressed to A Gray, Young Hearts Project, Level 3 McKinney House, Musgrave Park Hospital, Belfast BT9 7JB, UK)
}

\begin{abstract}
Agaricus campestris (mushroom) has been documented as a traditional treatment for diabetes. Here the administration of mushroom in the diet $(62.5 \mathrm{~g} / \mathrm{kg})$ and drinking water $(2.5 \mathrm{~g} / \mathrm{l})$ countered the hyperglycaemia of streptozotocindiabetic mice. An aqueous extract of mushroom (1 mg/ $\mathrm{ml})$ stimulated 2-deoxyglucose transport (2.0-fold), glucose oxidation (1.5-fold) and incorporation of glucose into glycogen $(1 \cdot 8$-fold $)$ in mouse abdominal muscle. In acute $20 \mathrm{~min}$ tests, $0 \cdot 25-1 \mathrm{mg} / \mathrm{ml}$ aqueous extract of mushroom evoked a stepwise $3 \cdot 5$ - to $4 \cdot 6$-fold stimulation of insulin secretion from the BRIN-BD11 pancreatic B-cell line. This effect was abolished by $0.5 \mathrm{mM}$ diazoxide and prior exposure to extract did not affect subsequent stimulation of insulin secretion by $10 \mathrm{mM} \mathrm{L}$-alanine, thereby negating a detrimental effect on cell viability. The effect of extract was potentiated by $16.7 \mathrm{mM}$ glucose,
\end{abstract}

L-alanine (10 mM) and IBMX (1 $\mathrm{mM})$, and a depolarising concentration of $\mathrm{KCl}(25 \mathrm{mM})$ did not augment the insulin-releasing activity of mushroom. Activity of the extract was found to be heat stable, acetone soluble and unaltered by exposure to alkali, but decreased with exposure to acid. Dialysis to remove components with molecular mass $<2000 \mathrm{Da}$ caused a $40 \%$ reduction in activity. Sequential extraction with solvents revealed insulin-releasing activity to be greatest in polar fractions. Lack of haemagglutinin activity with extract activity indicated that activity was unlikely to be due to a lectin-mediated event. These results demonstrate the presence of antihyperglycaemic, insulin-releasing and insulin-like activity in $A$. campestris.

Journal of Endocrinology (1998) 157, 259-266

\section{Introduction}

Throughout the world many traditional plant treatments for diabetes exist (Bailey \& Day 1989). However, few have received scientific or medical scrutiny and the World Health Organisation has recommended accordingly that traditional plant treatments for diabetes warrant further evaluation (World Health Organisation 1980). Administration of an edible mushroom to streptozotocin (STZ)diabetic mice countered the initial reductions in plasma insulin and pancreatic insulin concentration and improved the hypoglycaemic effect of exogenous insulin (Swanston-Flatt et al. 1989).

To understand better the mechanisms by which mushroom ameliorates hyperglycaemia, the effect of an aqueous extract of mushroom on glucose metabolism by isolated murine abdominal muscle and on insulin secretion by BRIN-BD11 cells was investigated. Since the ability of lectins isolated from mushrooms (Agaricus campestris, A. bisporus) to enhance insulin release by isolated rat islets of Langerhans has been documented (Ewart et al. 1975, Ahmad et al. 1984a,b), the potential presence of lectins in aqueous extracts of mushroom was also investigated.

\section{Materials and Methods}

Plant material

Dried fruiting bodies of mushroom (A. campestris) obtained from a commercial source (Whitworths Ltd, Wellingborough, Northants, UK) were homogenised to a fine powder and stored at room temperature $\left(20 \pm 2{ }^{\circ} \mathrm{C}\right)$ in opaque screw-topped jars until use. An aqueous extract of mushroom was prepared by immersion of the powdered material at $25 \mathrm{~g} / \mathrm{l}$ in boiling (distilled) water, and infused for $15 \mathrm{~min}$. The suspension was filtered (Whatman no. 1 filter paper) and stored at $-20{ }^{\circ} \mathrm{C}$. For consumption as drinking fluid, the extract was diluted 10-fold with tap water (equivalent to $2 \cdot 5 \mathrm{~g} / \mathrm{l}$ ). For in vitro studies, aliquots of extract were brought to dryness under vacuum (Savant Speedvac; Savant Instrumentation Incorp., Framingdale, NY, USA) and reconstituted in incubation buffer. To account for possible differences in potency, test and control incubations within a single experiment using isolated muscle or BRIN-BD11 cells were always conducted using the same batch of extract. This allowed for variation in potency of different batches of extract apparent in some insulin-release experiments. 


\section{Animal studies}

Male mice derived from a colony maintained at Aston University, Birmingham, UK (Flatt \& Bailey 1981) were used at 21-24 weeks of age. The mice were housed in an air conditioned room at $22 \pm 2{ }^{\circ} \mathrm{C}$ with a lighting schedule of $12 \mathrm{~h}$ light (0800-2000 h) and $12 \mathrm{~h}$ darkness. Animals had free access to a standard pellet diet (Mouse Breeding diet, Pillsbury Ltd, Birmingham, UK) and tap water. The overall nutrient composition of the diet was $36 \cdot 2 \%$ carbohydrate, $20 \cdot 9 \%$ protein, $4 \cdot 4 \%$ fat and $38.5 \%$ fibre with a metabolisable energy content of $1 \cdot 18 \mathrm{MJ} / 100 \mathrm{~g}$. The experimental procedure for in vivo studies was similar to that previously described (Swanston-Flatt et al. 1989). Dried fruiting bodies of mushroom were incorporated into the diet $(62.5 \mathrm{~g} / \mathrm{kg})$ and drinking water $(2.5 \mathrm{~g} / \mathrm{l})$ of groups of seven mice 5 days prior to and subsequent to intraperitoneal administration of STZ (Sigma Chemical Co., Poole, Dorset, UK) at $200 \mathrm{mg} / \mathrm{kg}$ body weight in $0 \cdot 1 \mathrm{M}$ sodium citrate buffer ( $\mathrm{pH} 4 \cdot 5$ ). Daily measures of body weight, food intake and fluid intake were made. Non-fasting blood samples obtained from the cut tail-tips of conscious mice were collected on days 12 and 20 for plasma glucose analysis (Stevens 1971). Groups of six normal mice and six STZ-treated mice with free access to unsupplemented diet and drinking water were used as control. It has previously been established that incorporation of mushroom into the diet and drinking water has no effect on glucose homeostasis of normal mice (Swanston-Flatt et al. 1989).

\section{Glucose transport and glucose metabolism in vitro}

Recently weaned non-fasting male mice (3-5 weeks old) were killed by cervical dislocation and squares of abdominal muscle (approximately 10-20 mg) were prepared. Incubations were performed using Krebs-Ringer bicarbonate buffer supplemented with $2 \%$ insulin-free BSA (KRB-BSA; $118 \mathrm{mM} \mathrm{NaCl}, 25 \mathrm{mM} \mathrm{NaHCO}$, $5 \mathrm{mM}$ $\mathrm{KCl}, 1.28 \mathrm{mM} \mathrm{CaCl}_{2}, 1.18 \mathrm{mM} \mathrm{MgSO}_{4}, 1.17 \mathrm{mM}$ $\mathrm{KH}_{2} \mathrm{PO}_{4}$ ). Flasks were sealed with rubber stoppers (Subaseal; Gallenkamp, London, UK) were gently shaken (92 cycles/min) throughout incubation and gassed with $95 \% \mathrm{O}_{2}: 5 \% \mathrm{CO}_{2}$ for $15-20 \mathrm{~min}$ before and for the initial $5 \mathrm{~min}$ of incubation.

To determine glucose uptake, muscle squares were incubated at $30^{\circ} \mathrm{C}$ for $30 \mathrm{~min}$ in $1 \mathrm{ml} \mathrm{KRB-BSA}$ supplemented with $2 \mathrm{mM}$ sodium pyruvate, $0 \cdot 1 \mu \mathrm{Ci} / \mathrm{ml}$ 2-deoxy-D-[1- $\left.{ }^{3} \mathrm{H}\right]$ glucose, $0 \cdot 01 \mu \mathrm{Ci} / \mathrm{ml} \mathrm{L}-\left[1-{ }^{14} \mathrm{C}\right]$ glucose (Amersham Life Science; Amersham, Bucks, UK) in the presence and absence of $10^{-8} \mathrm{M}$ human insulin (Sigma) and $1 \mathrm{mg} / \mathrm{ml}$ extract of mushroom. This concentration of insulin was chosen to represent a significant but submaximal stimulation of glucose uptake and oxidation within this preparation. After incubation, tissue was removed, blotted, hydrolysed in $0.5 \mathrm{ml} 1 \mathrm{M} \mathrm{NaOH}\left(85^{\circ} \mathrm{C}, 1 \mathrm{~h}\right)$ and counted for ${ }^{3} \mathrm{H}$ and ${ }^{14} \mathrm{C}$ radioactivity in HiSafe II scintil- lant (Fisons; Loughborough, Leics, UK). The extracellular fluid volume of the muscle was determined from the amount of the non-transported $\mathrm{L}-\left[1-{ }^{14} \mathrm{C}\right] \mathrm{glucose}$, and this was taken into account in the calculation of tissue 2-deoxy-D-[1- $\left.{ }^{3} \mathrm{H}\right]$ glucose uptake, expressed as d.p.m./mg wet weight muscle per $h$.

Oxidative glucose metabolism to $\mathrm{CO}_{2}$ and incorporation of glucose into glycogen were determined by incubation of muscle at $37^{\circ} \mathrm{C}$ for $60 \mathrm{~min}$ in $1 \mathrm{ml} \mathrm{KRB-BSA}$ supplemented with $10 \mathrm{mM}$ glucose, $0.5 \mu \mathrm{Ci} / \mathrm{ml} \mathrm{D-[U-}$ ${ }^{14} \mathrm{C}$ glucose (Amersham Life Science) in the presence and absence of $10^{-8} \mathrm{M}$ human insulin and $1 \mathrm{mg} / \mathrm{ml}$ extract of mushroom. Following incubation, $0.1 \mathrm{ml} 1 \mathrm{M} \mathrm{NaOH}$ was carefully injected through the rubber stopper onto a corrugated filter paper plug (Whatman no. 1) in a centre well. Flasks were then placed on ice for $5 \mathrm{~min}$ after which the tissue was removed for glycogen analysis. Flasks were re-stoppered and $0 \cdot 1 \mathrm{ml} 3 \mathrm{M} \mathrm{HClO}_{4}$ was injected into the incubation medium and allowed to stand for $1 \mathrm{~h}$ at room temperature. ${ }^{14} \mathrm{C}$ radioactivity of the filter paper was then counted in scintillant. $\mathrm{CO}_{2}$ production was expressed as nmol $\mathrm{CO}_{2} / \mathrm{mg}$ wet weight muscle per h. The incorporation of glucose into glycogen was determined by hydrolysis of the tissue with $1 \mathrm{ml} 1 \mathrm{M} \mathrm{KOH}\left(85^{\circ} \mathrm{C}, 2 \mathrm{~h}\right)$. Once cooled glycogen was precipitated with $95 \%$ ethanol and the glycogen pellet hydrolysed with $1 \mathrm{ml} \mathrm{M} \mathrm{H} \mathrm{H}_{2} \mathrm{SO}_{4}$ $\left(85^{\circ} \mathrm{C}, 2 \mathrm{~h}\right)$, which was allowed to cool and neutralised with $5 \mathrm{M} \mathrm{NaOH}$. Aliquots $(0.5 \mathrm{ml})$ were added to scintillant and counted for ${ }^{14} \mathrm{C}$ radioactivity. Incorporation of glucose into glycogen was expressed as nmol glucose equivalents/mg wet weight muscle per h.

\section{Insulin secretion in vitro}

BRIN-BD11 cells, produced by electrofusion of immortal RINm5F cell with New England Deaconess Hospital rat pancreatic B-cell, were used to evaluate insulin secretion. The generation and basic characteristics of this glucoseresponsive insulin-secreting cell line have been described elsewhere (McClenaghan et al. 1996). BRIN-BD11 cells were cultured at $37^{\circ} \mathrm{C}$ in a humidified atmosphere of $5 \%$ $\mathrm{CO}_{2}$ in air in RPMI-1640 medium containing $11.1 \mathrm{mM}$ glucose, $10 \%$ foetal calf serum and antibiotics (50 000 IU/1 penicillin and streptomycin). Cells were seeded at a concentration of $0 \cdot 2 \times 10^{6}$ cells/well in 24 -well plates (Falcon, New Jersey, USA) and allowed to attach overnight prior to acute tests. Wells were washed three times with Krebs-Ringer bicarbonate buffer (KRB; $115 \mathrm{mM}$ $\mathrm{NaCl}, 4.7 \mathrm{mM} \mathrm{KCl}, 1.3 \mathrm{mM} \mathrm{CaCl} 2,1.2 \mathrm{mM} \mathrm{KH}_{2} \mathrm{PO}_{4}$, $1.2 \mathrm{mM} \mathrm{MgSO}_{4}, 24 \mathrm{mM} \mathrm{NaHCO}_{3}, 10 \mathrm{mM}$ Hepes free acid, $1 \mathrm{~g} / 1 \mathrm{BSA}, 1.1 \mathrm{mM}$ glucose; $\mathrm{pH} 7 \cdot 4)$ and preincubated for $40 \mathrm{~min}$ at $37^{\circ} \mathrm{C}$. Unless otherwise stated, cells were then incubated for $20 \mathrm{~min}$ with $1 \mathrm{ml} \mathrm{KRB}$ at $1.1 \mathrm{mM}$ glucose in the absence and presence of plant extract and other test agents. Aliquots were removed from each well, centrifuged $\left(700 \mathrm{~g}, 5 \mathrm{~min}, 4^{\circ} \mathrm{C}\right)$ and stored at 
Table 1 Effects of mushroom administered in the diet $(62.5 \mathrm{~g} / \mathrm{kg})$ and drinking water $(2.5 \mathrm{~g} / \mathrm{l})$ on body weight, fluid intake, food intake and plasma glucose concentrations of streptozotocin-treated mice. Values are means \pm S.E.M. for groups of six or seven mice

\begin{tabular}{|c|c|c|c|}
\hline & Normal mice & STZ mice & $\begin{array}{l}\text { STZ mice+ } \\
\text { mushroom }\end{array}$ \\
\hline \multicolumn{4}{|l|}{ Body weight (g) } \\
\hline Study day 0 & $45 \cdot 5 \pm 2 \cdot 90$ & $42 \cdot 3 \pm 0 \cdot 94$ & $44 \cdot 0 \pm 1 \cdot 44$ \\
\hline Study day 20 & $48 \cdot 1 \pm 1 \cdot 19$ & $37 \cdot 7 \pm 2 \cdot 38^{* *}$ & $41 \cdot 1 \pm 1 \cdot 08 \dagger$ \\
\hline \multicolumn{4}{|c|}{ Fluid intake (ml/day) } \\
\hline Study day 0 & $4 \cdot 5 \pm 0 \cdot 20$ & $4 \cdot 3 \pm 0 \cdot 24$ & $4 \cdot 3 \pm 0 \cdot 03$ \\
\hline Study day 20 & $5 \cdot 2 \pm 0 \cdot 31$ & $10 \cdot 0 \pm 0 \cdot 50^{* \star *}$ & $7 \cdot 6 \pm 0.67^{* *} \dagger$ \\
\hline \multicolumn{4}{|c|}{ Food intake (g/day) } \\
\hline Study day 0 & $4 \cdot 4 \pm 0 \cdot 49$ & $4 \cdot 4 \pm 0 \cdot 43$ & $4 \cdot 3 \pm 0 \cdot 43$ \\
\hline Study day 20 & $5 \cdot 2 \pm 0 \cdot 40$ & $4 \cdot 9 \pm 0 \cdot 40$ & $5 \cdot 6 \pm 1 \cdot 18$ \\
\hline \multicolumn{4}{|c|}{ Plasma glucose $(\mathrm{mmol} / \mathrm{l})$} \\
\hline Study day 12 & $6 \cdot 6 \pm 0 \cdot 45$ & $13 \cdot 5 \pm 1 \cdot 68^{* *}$ & $6 \cdot 7 \pm 0.92 \dagger \dagger$ \\
\hline Study day 20 & $9 \cdot 9 \pm 0 \cdot 74$ & $22 \cdot 3 \pm 3 \cdot 06^{* *}$ & $9 \cdot 7 \pm 0 \cdot 71+\dagger$ \\
\hline
\end{tabular}

$-20^{\circ} \mathrm{C}$ for insulin assay (Flatt \& Bailey 1981). Concentrations of plant extract tested $(0 \cdot 25,0 \cdot 5,1 \mathrm{mg} / \mathrm{ml})$ did not influence the cell viability of BRIN-BD11 cells during the test period as evaluated by the modified neutral red assay (Hunt et al. 1987).

\section{Effect of chemical treatments of mushroom extract on insulin secretion}

To evaluate the nature of the insulin-releasing component(s) the aqueous extract of mushroom was subjected to heat, overnight dialysis, acid-alkali or acetone treatment. Heat: aqueous extract was boiled for $1 \mathrm{~h}$ immediately after preparation. Dialysis: aqueous extract was dialysed overnight (Spectra/Por molecular mass cut-off 2000 Da; Spectrum, Los Angeles, CA, USA) against Millipore water at $4{ }^{\circ} \mathrm{C}$. Acid-alkali treatment: aliquots of aqueous extract were added to $5 \mathrm{M} \mathrm{HCl}$ or $5 \mathrm{M} \mathrm{NaOH}$ to produce $0 \cdot 1 \mathrm{M}$ $\mathrm{HCl}$ or $0 \cdot 1 \mathrm{M} \mathrm{NaOH}$, allowed to stand at room temperature overnight, then neutralised. Acetone treatment: $1 \mathrm{ml}$ of aqueous extract $(1 \mathrm{mg} / \mathrm{ml})$ was added to $10 \mathrm{ml}$ ice-cold acetone, allowed to stand for $30 \mathrm{~min}$ and centrifuged $(800 \mathrm{~g}, 5 \mathrm{~min})$ to obtain acetone-soluble and acetoneinsoluble fractions. Aliquots of untreated extract and modified aqueous extracts were dried under vacuum. All modified aqueous extracts were freshly reconstituted in $\mathrm{KRB}$ and effects on insulin secretion at a concentration equivalent to $1 \mathrm{mg} / \mathrm{ml}$ compared with untreated extract.

In another series of experiments mushroom fruiting bodies were subjected to sequential extraction by increasingly polar solvents. Plant material $(0 \cdot 25 \mathrm{~g})$ was placed in
$5 \mathrm{ml}$ of hexane, agitated for $15 \mathrm{~min}$ and centrifuged (950 $\mathrm{g}, 5 \mathrm{~min})$. The precipitate was dried under vacuum and extracted with a further $5 \mathrm{ml}$ hexane and centrifuged (as before). The extraction supernatant was pooled and filtered (Whatman no. 1) and the volume adjusted to $10 \mathrm{ml}$ with hexane. The extraction precipitate (dried under vacuum) was subsequently extracted (as above) with $2 \times 5 \mathrm{ml}$ volumes of ethyl acetate, then methanol and finally with water. All extract fractions were freshly reconstituted in KRB and effects on insulin secretion at a concentration equivalent to $1 \mathrm{mg} / \mathrm{ml}$ compared with those of untreated extract.

Haemagglutination assay of lectin presence in aqueous extract

Serial dilutions of aqueous extract of mushroom were performed using PBS (137 mM NaCl, 2.68 mM KCl, $14.07 \mathrm{mM} \mathrm{KH} \mathrm{KO}_{4}, 204 \mathrm{mM} \mathrm{Na} 2 \mathrm{HPO}_{4} ; \mathrm{pH} \mathrm{7.4)} \mathrm{in}$ $\mathrm{V}$-shaped bottom microtitre wells to which an equal volume of freshly prepared $2 \%$ erythrocyte suspension (human $\mathrm{O} \mathrm{Rh}$ - or pooled rat; in PBS) was added. Wells were incubated for $1 \mathrm{~h}$ at room temperature and the titre read visually as being equal to the dilution in the last well to show agglutination (as manifested by an evenly distributed layer of cells over the whole well bottom). The haemagglutinin activities of normal aqueous extract (normal extract), aqueous extract produced by a 15 min cold infusion instead of hot infusion (cold extract), and cold extract subsequently brought to the boil and allowed to infuse for $15 \mathrm{~min}$ (heated extract) were examined, and for each a titre value was obtained. 
Table 2 Effect of aqueous mushroom extract on glucose uptake and glucose metabolism by isolated mouse abdomen muscle during incubations in the absence and presence of $10^{-8} \mathrm{M}$ insulin. Values are means \pm S.E.M. with number of replicates in parentheses

\begin{tabular}{|c|c|c|c|c|}
\hline & Control & $\begin{array}{l}\text { Insulin } \\
\left(10^{-8} \mathrm{M}\right)\end{array}$ & $\begin{array}{l}\text { Extract } \\
(1 \mathrm{mg} / \mathrm{ml})\end{array}$ & $\begin{array}{l}\text { Insulin + } \\
\text { extract }\end{array}$ \\
\hline Glucose uptake (d.p.m./mg/h) & $166 \pm 27(6)$ & $362 \pm 81^{*}(6)$ & $327 \pm 43^{*}(6)$ & $364 \pm 81^{*}(6)$ \\
\hline Incorporation of glucose into glycogen $(\mathrm{nmol} / \mathrm{mg} / \mathrm{h})$ & $0 \cdot 13 \pm 0.03(11)$ & $0 \cdot 28 \pm 0 \cdot 06^{*}(11)$ & $0 \cdot 24 \pm 0 \cdot 04^{*}(11)$ & $0 \cdot 31 \pm 0 \cdot 06^{*}(11)$ \\
\hline
\end{tabular}

${ }^{*} P<0.05$ compared with control incubations in the absence of added insulin and extract.

\section{Statistical analysis}

Data were evaluated using Student's unpaired $t$-test, and one- or two-way ANOVA where appropriate. Groups were considered to be significantly different if $P<0 \cdot 05$. When a significant $F$ value was obtained for ANOVA the differences of all pairs were tested using StudentNewman-Keuls multiple comparisons test. If s.D.s were significantly different (Barlett's test for homogeneity of variances) data were transformed $(\log 10[\mathrm{x}])$.

\section{Results}

\section{Studies in vivo}

Compared with normal mice, STZ administration resulted in significant $(P<0 \cdot 05)$ weight loss, polydipsia and hyperglycaemia (Table 1). Administration of mushroom in the diet and drinking water significantly decreased the hyperglycaemia by study day $12(6 \cdot 7 \pm 0.9 \mathrm{mM}$ compared with $13.5 \pm 1.7 \mathrm{mM}$ for STZ controls; $P<0 \cdot 01)$ to a level not significantly greater than that of normal mice (Table 1).

\section{Glucose transport and glucose metabolism in vitro}

Aqueous extract of mushroom $(1 \mathrm{mg} / \mathrm{ml})$ increased glucose uptake (1.97-fold), ${ }^{14} \mathrm{CO}_{2}$ production $(1 \cdot 49$-fold $)$ and glycogenesis (1.84-fold) during incubations without insulin. Combination of mushroom extract and insulin did not significantly alter the stimulatory effect compared with agent alone (Table 2).

\section{Insulin secretion in vitro}

Aqueous extract of mushroom $(0 \cdot 25-1 \mathrm{mg} / \mathrm{ml})$ had a dose-dependent stimulatory effect on insulin secretion from BRIN-BD11 cells at $1 \cdot 1 \mathrm{mM}$ glucose (Fig. 1). The presence of $0.5 \mathrm{mM}$ diazoxide inhibited the stimulatory effect of the extract, indicating that enhancement of insulin release was not a mere consequence of cellular damage. Consistent with this view, prior exposure of BRIN-BD11 cells to $0 \cdot 25-1 \mathrm{mg} / \mathrm{ml}$ extract for $20 \mathrm{~min}$ did not alter the subsequent $3 \cdot 5$ - to $4 \cdot 6$-fold insulin secretory response to $10 \mathrm{mM}$ L-alanine (data not shown). The insulin-releasing effect of $1 \mathrm{mg} / \mathrm{ml}$ extract was markedly potentiated by the presence of high $(16.7 \mathrm{mM})$ glucose (Fig. 2a), whereas $10 \mathrm{mM}$ L-alanine did not significantly enhance the insulinotropic effect (Fig. 2b). The action of the extract $(1 \mathrm{mg} / \mathrm{ml})$ was not potentiated by $1 \mathrm{mM}$ 3-isobutyl-1-methylxanthine (IBMX), which increases cyclic AMP in insulin-secreting cells (Sharp 1979) (Fig. 2c). In the absence of added extract a depolarising concentration of $\mathrm{KCl}(25 \mathrm{mM})$ markedly enhanced the insulin response to $16.7 \mathrm{mM}$ glucose

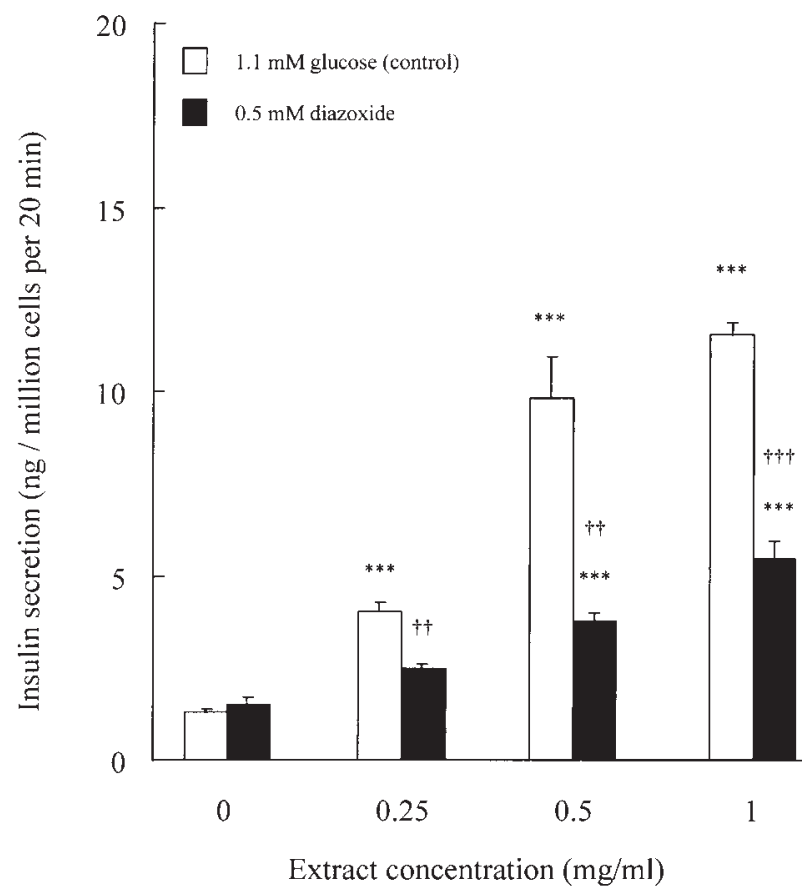

Figure 1 Effects of aqueous extract of mushroom on insulin secretion by BRIN-BD11 cells in the absence and presence of $0.5 \mathrm{mM}$ diazoxide. Means for groups of six observations; standard errors indicated by vertical bars. ${ }^{* *} P<0 \cdot 001$ compared with control incubations without extract; $\uparrow+P<0 \cdot 01,+\uparrow+P<0 \cdot 001$ compared with incubations at the same extract concentration without diazoxide. 
(a)

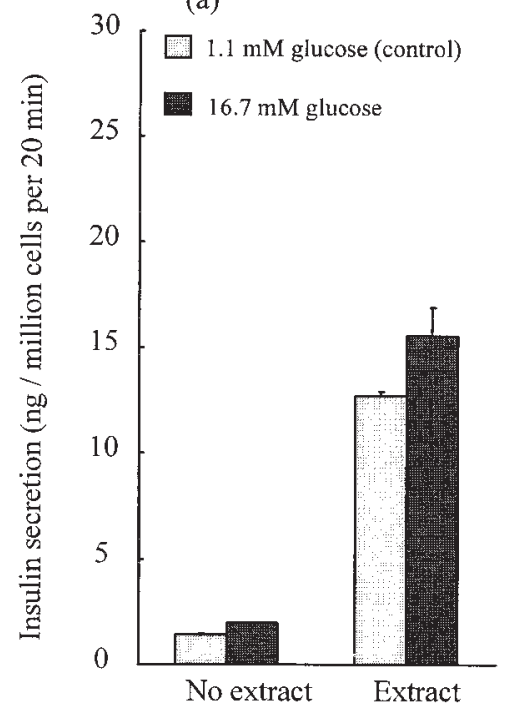

(c)

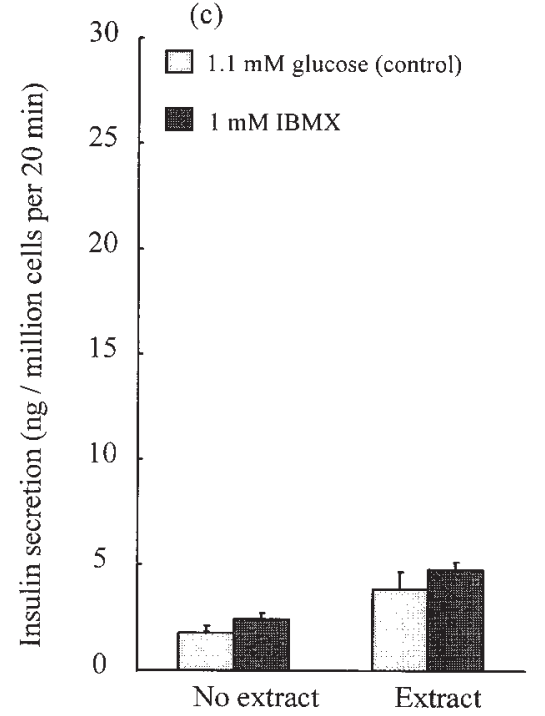

(b)

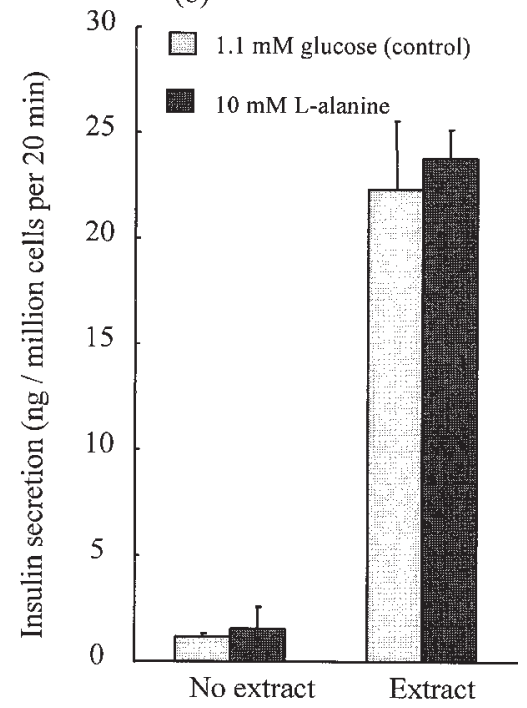

(d)

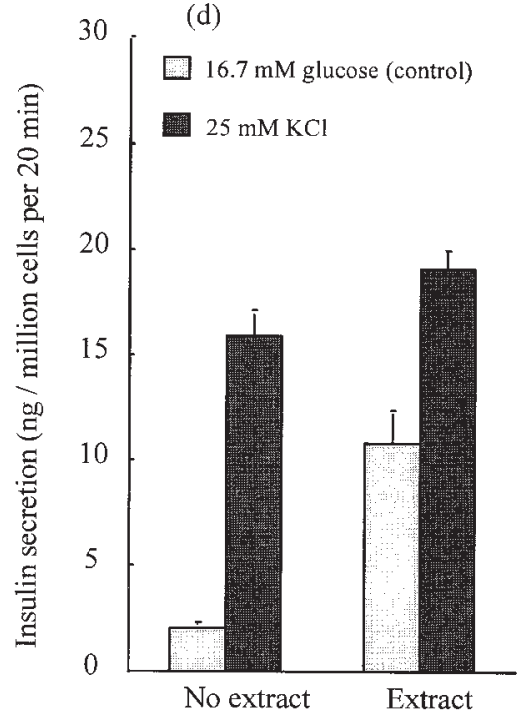

Figure 2 Effects of (a) glucose, (b) L-alanine, (c) IBMX, or (d) $\mathrm{KCl}$ on the insulin-releasing actions of aqueous extract $(1 \mathrm{mg} / \mathrm{ml})$ of mushroom. Means for groups of six observations; standard errors indicated by vertical bars. Two-way ANOVA revealed: (a) extract effect $(P<0.001)$, glucose effect $(P=0.007)$ and extract-glucose interaction $(P<0.045)$; (b) extract effect $(P<0.001)$, L-alanine effect $(P<0.001)$ and extract-L-alanine interaction $(P<0.001)$; (c) extract effect $(P<0 \cdot 001)$, IBMX effect $(P=0 \cdot 032)$ and extract-IBMX interaction (not significant); (d) extract effect $(P<0 \cdot 001), \mathrm{KCl}$ effect $(P<0 \cdot 001)$ and extract- $\mathrm{KCl}$ interaction $(P<0 \cdot 001)$.

(Fig. 2d). However, depolarised BRIN-BD11 cells did not show a further insulin-releasing effect with mushroom extract.

Prolonged exposure to heat did not significantly alter the insulin-releasing activity of plant extract (Table 3). Dialysis reduced the insulin-releasing activity as compared with untreated extract. Alkali-exposed extract had greater insulin-releasing effects on BRIN-BD11 cells than acidexposed. The insulin-releasing activity was completely retained in the acetone-soluble fraction (Table 3). All sequential extraction fractions of mushroom had a reduced insulin-releasing activity compared with normal aqueous 
Table 3 Effect of heat, dialysis, acid-alkali treatment and acetone treatment on ability of aqueous mushroom extract to enhance insulin secretion by BRIN-BD11 cells. Values are means \pm S.E.M. for groups of six observations

\section{Insulin secretion} (ng/10 ${ }^{6}$ cells/20 min)

\section{Test}

Control (without extract)

Untreated extract

Boiled extract

Dialysed extract

Acid-exposed extract

Alkali-exposed extract

Acetone-insoluble extract

Acetone-soluble extract

${ }^{* *} P<0 \cdot 01,{ }^{* * *} P<0 \cdot 001$ compared to control incubations; ${ }^{+} P<0 \cdot 05$,

${ }^{+++} P<0.001$ compared to incubations with untreated extract; $++P<0.01$ compared to incubations with acid-exposed extract; $\neq \neq \neq P<0.001$ compared to incubations with acetone-insoluble extract.

extract of mushroom (Fig. 3). Although less potent than the normal aqueous extract, the water fraction of mushroom (produced by sequential extraction) had the greatest insulin-releasing activity (Fig. 3). Both the ethyl acetate and methanol sequential extract fractions retained some insulin-releasing activity. Hexane fraction failed to alter insulin secretion by BRIN-BD11 cells.

\section{Haemagglutination assay of lectin presence in aqueous extract}

There was no observed haemagglutinin activity by aqueous extract of mushroom (titre value $0, n=3$ ). Titre values for human erythrocytes and for rat erythrocytes (8 and 4 respectively, $n=3$ ) were obtained for extract produced by cold infusion (cold extract), indicating the presence of haemagglutinin activity. The activity of this extract was subsequently lost by heating (to produce heated extract) (titre value $0, n=3$ ).

\section{Discussion}

The present study has confirmed that chronic administration of mushroom $(62.5 \mathrm{~g} / \mathrm{kg}$ of diet, $2.5 \mathrm{~g} / \mathrm{l}$ in place of drinking water) reduces hyperglycaemia of STZdiabetic mice (Swanston-Flatt et al. 1989). The antihyperglycaemic action may have been in part due to protection of B-cells against the cytotoxic action of STZ as evident by a retarded rate of insulin loss (Swanston-Flatt et al. 1989). However, this does not appear to account entirely for the glucose-lowering effect of the mushroom since glucose concentrations were held down even when insulin concentrations were very low (Swanston-Flatt et al. 1989) suggesting that mushroom may exert effects on insulin secretion and/or action. The present data demonstrate

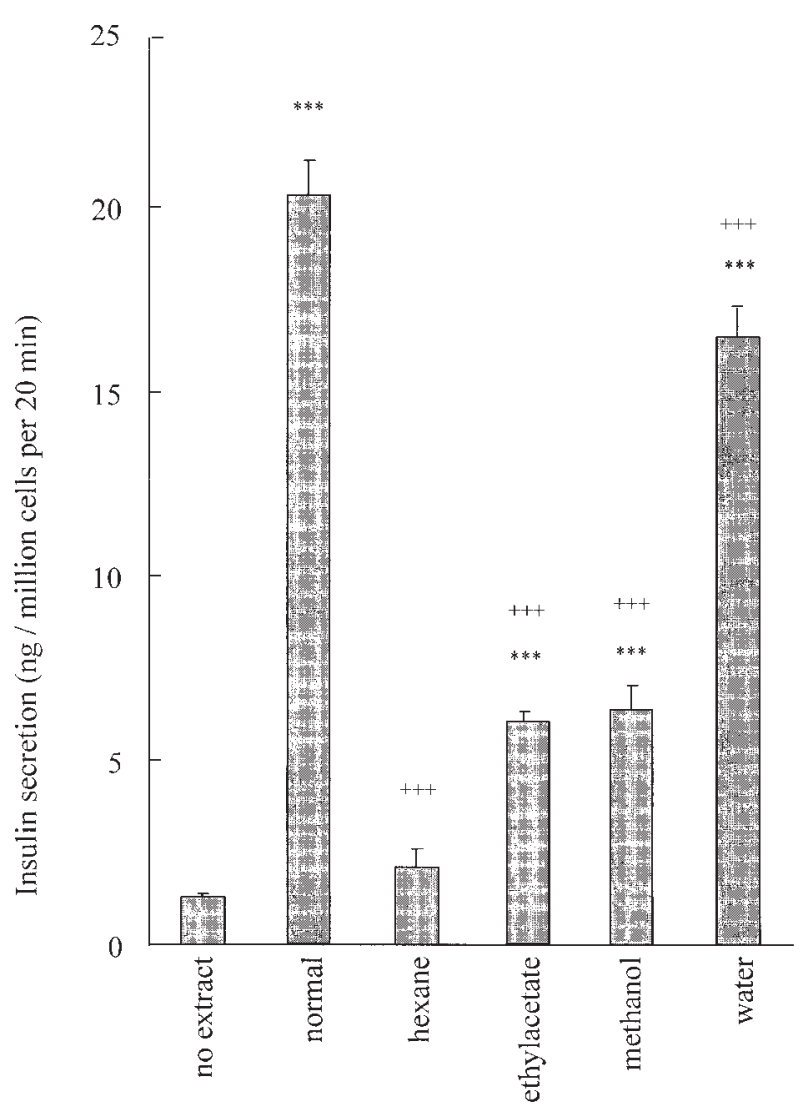

Extract fraction

Figure 3 Effect of sequential extraction by solvents with increasing polarity on insulin-stimulating effect of mushroom. All extracts were tested at concentrations equivalent to $1 \mathrm{mg} / \mathrm{ml}$. Means for groups of six observations; standard errors indicated by vertical bars. ${ }^{* *} P<0.001$ compared with incubations without extract; ${ }^{+++} P<0 \cdot 001$ compared with incubations with normal extract.

both extrapancreatic and pancreatic effects of aqueous mushroom extract.

Using an isolated mouse skeletal muscle preparation, aqueous extract of mushroom enhanced glucose transport and glucose metabolism in a similar magnitude to $10^{-8} \mathrm{M}$ insulin. Although this effect was observed in the absence of added insulin it does not preclude a possible involvement of residual insulin receptor binding within the muscle preparation. However, the lack of potentiation by combination of mushroom extract and insulin suggests that the extract is likely to act via pathways (at least terminally) that are utilised by insulin rather than entirely separate pathways. The effect of extract on glucose uptake differed from that of metformin, which exerts its effects on glucose transport via insulin-mediated enhanced peripheral glucose uptake (Bailey \& Puah 1986, Prager et al. 1986).

Incubations were performed with glucose-responsive BRIN-BD11 cells (McClenaghan et al. 1996) to 
investigate possible effects of aqueous extract of mushroom on insulin secretion in vitro. This revealed a stepwise dose-dependent stimulation of insulin secretion by mushroom extract at low (non-stimulatory) glucose concentration. Evaluation of cell viability using neutral red assay and the insulin-releasing action of L-alanine following exposure of BRIN-BD11 cells to extract argue against a simple cytotoxic action. Inhibition of the stimulatory effects of the extract with diazoxide supports this view. The established effects of diazoxide on the B-cell arising from activating $\mathrm{K}^{+}$-ATP channels (Trube et al. 1986) indicate involvement of $\mathrm{K}^{+}$-ATP channel closure in the stimulatory action of mushroom. Such an effect is reminiscent of the hypoglycaemic sulphonylureas, which promote insulin secretion by closure of $\mathrm{K}^{+}$-ATP channels, membrane depolarisation and stimulation of $\mathrm{Ca}^{2+}$ influx (Schwanstecher \& Panten 1994). The effect of the extract on insulin secretion was also potentiated by $16.7 \mathrm{mM}$ glucose, suggesting that B-cell glucose metabolism is able to augment the insulinotropic stimulus. Consistent with this view, L-alanine, which promotes insulin secretion through changes in $\mathrm{Na}^{+}$transport (Yada 1994), failed to affect the insulin-releasing action of mushroom. The stimulatory effect of mushroom extract was not evident in cells depolarised by $25 \mathrm{mM} \mathrm{KCl}$, suggesting that the extract does not exert intracellular effects as noted for sulphonylureas (Eliasson et al. 1996). Interestingly, the phosphodiesterase inhibitor, IBMX, did not potentiate the insulin-releasing effect of mushroom extract, raising the possibility that the extract may itself inhibit islet phosphodiesterase (Leibowitz et al. 1995).

Refinement of the extract indicated that the active insulin-releasing component(s) was heat stable, acetone soluble and unaltered by exposure to alkali. Overnight dialysis of extract reduced the insulin-releasing effect of aqueous plant extract by $40 \%$ and may give credence to the partial involvement of smaller molecules, in particular ions. Indeed, the results of sequential solvent extraction point to a cumulative effect of more than one active constituent, the activity largely polar in nature.

The active principle(s) in mushroom remain to be elucidated. Guanidine, a known hypoglycaemic substance related to the biguanide class of oral antidiabetic drugs, has been detected in edible mushroom (Windholtz 1983). Other species of mushroom (e.g. Amantia phalloides) have been reported to contain poisonous hypoglycaemic substances which deplete hepatic glycogen (Bever \& Zahnd 1979). In the present study, there was no evidence for a toxic effect of mushroom. It is possible that other nontoxic antihyperglycaemic substances are responsible for the observed insulin-like effects on muscle and the stimulation of insulin secretion in vitro. The ability of lectins isolated from mushrooms (A. campestris, A. bisporus) to enhance insulin release by isolated rat islets of Langerhans has been documented (Ewart et al. 1975, Ahmad et al. 1984a,b). However, heating the $A$. campestris lectin to $100{ }^{\circ} \mathrm{C}$ for
3 min abolished its activity (Ewart et al. 1975). Our data show that boiling for $1 \mathrm{~h}$ does not significantly alter the insulin-enhancing effect of the extract. Furthermore, lectin present in an extract of mushroom produced by cold infusion was removed by subsequent heating and was not in normal aqueous extract (produced by $15 \mathrm{~min}$ hot infusion). These results suggest that the antihyperglycaemic activity of mushroom is due to insulin-releasing and insulin-like activity not involving lectins. The nature of the active principle(s) and the mechanisms of action on insulin-secreting cells and muscle remain to be established.

\section{Acknowledgements}

These studies were supported by the Department of Health and Social Services, Northern Ireland and Northern Ireland Developmental Research Funding. The authors thank Dr Caroline Day and Dr Clifford J Bailey (Department of Biological and Pharmaceutical Sciences, Aston University, Birmingham, UK) for their helpful advice and discussions, and Dr Peter Kwaskowski (Department of Biological Sciences, University of Surrey, Guildford, UK) for guidance on lectin studies.

\section{References}

Ahmad N, Bansal AK \& Kidwai JR 1984a Effect of PHA-B fraction of Agaricus bisporus lectin on insulin release and ${ }^{45} \mathrm{Ca}^{2+}$ uptake by islets of Langerhans in vitro. Acta Diabetologica 21 63-70.

Ahmad N, Khan MM, Rastogi AK \& Kidwai JR $1984 b$ Effect of age on Agaricus bisporus PHA-B stimulated insulin release and ${ }^{45} \mathrm{Ca}^{2+}$ uptake in vitro by islets of Langerhans. Acta Diabetologica 21 349-355.

Bailey CJ \& Puah JA 1986 Effect of metformin on glucose metabolism in mouse soleus muscle. Diabète et Metabolisme 12 212-218.

Bailey CJ \& Day C 1989 Traditional treatments for diabetes. Diabetes Care 12 533-564.

Bever BO \& Zahnd GR 1979 Plants with oral hypoglycemic action. Quarterly Journal of Crude Drug Research 17 139-196.

Eliasson L, Renström E, Ämmälä C, Berggren P-O, Bertorello AM, Bokvist K, Chibalin A, Deeney JT, Flatt PR, Gabel J, Gromado J, Larsson O, Lindström P, Rhodes CJ \& Rorsman P 1996 PKC-dependent stimulation of exocytosis by sulfonylureas in pancreatic B cells. Science 271 813-815.

Ewart RBL, Kornfeld S \& Kipnis DM 1975 Effect of lectins on hormone release from isolated rat islets of Langerhans. Diabetes 24 705-714.

Flatt PR \& Bailey CJ 1981 Development of glucose in obese hyperglycaemic $(o b / o b)$ mice. Hormone and Metabolic Research 13 556-560.

Hunt SM, Chrzanowska C, Barnett CR, Brand HN \& Fawell JK 1987 A comparison of in vitro cytotoxicity assays and their application to water samples. Alternatives to Laboratory Animals $\mathbf{1 5}$ 20-29.

Leibowitz MD, Biswas C, Brady EJ, Conti M, Cullinan CA, Hayes NS, Manganiello VC, Saperstein R, Wang L, Zafian PT \& Berger J 1995 A novel insulin secretagogue is a phosphodiesterase inhibitor. Diabetes 44 67-74. 
McClenaghan NH, Barnet CR, Ah-Sing E, Abdelwahab YHA, O'Harte FPM, Yoon T-W, Swanston-Flatt SK \& Flatt PR 1996 Characterization of a novel glucose-responsive insulin-secreting cell line, BRIN-BD11, produced by electrofusion. Diabetes $\mathbf{4 5}$ 1132-1140.

Prager R, Schernthaser G \& Graf H 1986 Effect of metformin on peripheral insulin sensitivity in non-insulin dependent diabetes mellitus. Diabète et Metabolisme 12 346-350.

Schwanstecher C \& Panten U 1994 Interactive control by sulphonylureas and cytosolic nucleotides of the ATP-sensitive $\mathrm{K}^{+}$ channel in pancreatic B-cells. In Frontiers of Insulin Secretion and Pancreatic B-cell Research, pp 161-166. Eds PR Flatt \& S Lenzen. London: Smith-Gordon.

Sharp GWG 1979 The adenylate cyclase-cyclic AMP system in islets of Langerhans and its role in the control of insulin release. Diabetologia 16 287-297.

Stevens JF 1971 Determination of glucose by automatic analyser. Clinica Chimica Acta 32 199-201.

Swanston-Flatt SK, Day C, Flatt PR, Gould BJ \& Bailey CJ 1989 Glycemic effects of traditional European plant treatments for diabetes: studies in normal and streptozotocin diabetic mice. Diabetes Research 10 69-73.

Trube G, Rorsman P \& Ohno-Shosaku T 1986 Opposite effects of tolbutamide and diazoxide on ATP-dependent $\mathrm{K}^{+}$channel in mouse pancreatic B-cells. Pflugers Archiv 407 493-499.

World Health Organisation 1980 Second Report of the WHO Expert Committee on Diabetes Mellitus. Technical Report Series 646, p 66. Geneva: World Health Organisation.

Windholz M 1983 The Merck Index, edn 10. Rahway, New Jersey: Merck \& Co.

Yada T 1994 Action mechanisms of amino acids in pancreatic B-cells. In Frontiers of Insulin Secretion and Pancreatic B-cell Research, pp 161-166. Eds PR Flatt \& S Lenzen. London: Smith-Gordon.

Received 30 June 1997

Revised manuscript received 23 October 1997 Accepted 28 November 1997 